\title{
Verbal Word-Formation in the Lower Kolyma Subdialect of the Even Language
}

\author{
Sardana I. Sharina* \\ M.K. Ammosov North-Eastern Federal University \\ 58 Belinsky Str., Yakutsk, 677000, Russia
}

Received 06.03.2018, received in revised form 10.04.2018, accepted 14.04.2018

The system of verbal word formation in the Lower Kolyma subdialect of the Even language, which does not have a systematic description, is studied in the article. Referring to the western dialect, the Lower Kolyma subdialect has a number of distinctive features at all the language levels. In the sphere of verbal word formation, these differences are manifested in the phonetic and lexical features of the subdialect, in the suffixes of certain morphological categories of verb and their structure, as well as in the frequency of the indicators use.

This article is based on the field materials of the author collected during the field expeditions in the Lower Kolyma District of the Republic of Sakha (Yakutia) in 2013-2015.

Keywords: the Even language; Lower Kolyma subdialect, word-formation of verbs, denominative word-formation, deverbative word-formation.

DOI: 10.17516/1997-1370-0255.

Research area: philology.

The Lower Kolyma subdialect of the Even language has not got a systematic description yet; in the existing classifications it was singled out as a separate unit by A.A. Burykin only in 2004 (Burykin, 2004: 79). The Lower Kolyma subdialect significantly differs from the eastern subdialects of the Even language, since it has a number of peculiarities at all the language levels (Sharina, 2014). The subdialect also reveals distinct differences in the field of verb morphology.

Verb occupies a central place in the grammatical system of the Even language not only due to the significant lexical composition, but also due to the rich variety of grammatical categories. There are two ways of forming the Even verb: suffixal derivation and conversion. The main way of replenishing the verbal lexicon in the Even language is suffixal formation of new verb stems. Verbal word formation is considered in almost all the dialectological and grammatical works devoted to the Even language, where the composition of verbalizers - verb-forming suffixes - is represented, and according to them, the principles of verbalization in all the Even subdialects and dialects are basically the same (Sharina, 2017). The differences are in the phonetic and lexical peculiarities of the dialects themselves, in the composition of the suffixes of certain morphological categories and their

(C) Siberian Federal University. All rights reserved

* Corresponding author E-mail address: si.sharina@s-vfu.ru 
structure, as well as in the frequency of various indicators use.

In the Even language verbal stems are divided into non-derivative (root) ones and derived. In the Lower Kolyma subdialect there are a lot of non-derivative verbal stems that do not have word-forming elements and are currently difficult to define. Mostly they coincide with the verbal stems of other subdialects and dialects, i.e. they are all-Evens. They include the following verbs: бйдэй (to be), о̄дай (to become), н’эктэй (to do), га̄дай (to take), бактай (to find), тэвдэй (to sit), тиктэй (to fall), уэндэй (to go). These stems have only phonetic differences in the Lower Kolyma subdialect, for example: $б \bar{y} \partial э \breve{u}$ (to

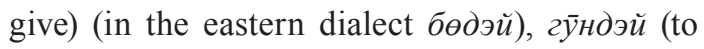
talk) (in the eastern dialect гөндэй).

Derived stems are divided into three types: denominal suffixless, denominal suffixal and deverbative suffixal.

Denominal suffixless verbal stems are syncretic forms of the name/verb type. They are formed from the stems of names with the help of tense and mood suffixes. According to the principles of semantic classification developed by S.L. Charekov (Charekov, 2004), these verbs can be grouped into the following types of actions from the syncretic forms.

Action with the help of an object designated by the original syncretic stem: чэээт (a fishing $\mathrm{rod} /$ fishing with a fishing rod), гид (a spear/to pierce with a spear).

Action aimed at an object indicated by the initial syncretic stem: $h \ni \partial$ 'э (an Even dance/ to dance an Even dance), талак (slices of frozen fish or meat/to slice frozen fish or meat).

Action of an object itself: гиавйн (dawn/ to dawn), һилӭh (dew/dewfall), авди (thunder/to thunder, hунуэ (wind/ to blow (about the wind).

Action that denotes an object production or a concept implementation: гэрбэ (a name/ to call, to name), Һокан (boasting, conceit, arrogance/to boast, to become conceited, to talk big), бӭргӭ (fat, obese/to get fat, to become obese).

Action in the sphere of an object or the state of an object: удь (a track/to track), нулгэ (а nomad camp/to lead a nomadic life).

The above types of actions, which are syncretic forms of the name/verb type are a less productive group in the Lower Kolyma subdialect than the verbal stems, formed with the help of suffixes.

Denominal suffixal verbal stems are formed from nominal stems with the help of special suffixes. The following ones are typical for the Lower Kolyma subdialect:

-да/-дэ, -та/-тэ form the verbs with the meaning of action from the nouns with the help of an object or this object use, for example: тэдэнтэдэци (to use a bedding of deerskin) from пэдэн (a bedding, a deerskin used as a bedding), лохогайдадай (to dance a Yukaghir dance) from лохоганули (a Yukaghir dance), чалмидадай (to eat the guts of a deer or moose), from чалми (guts);

-p/-pa/-рэ, -ла/-лэ are the variants of suffixes -да /-дэ form verbs from the noun stems and adjectives with the meaning of an action with the help of an object or this object use, and with the meaning of acquiring this characteristic, for example: алӑкладай (to harness in straps) from алӑк (a harness, a strap), убурдай (to raise, to lift)

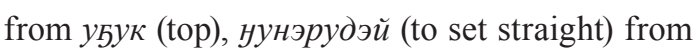
уун (straight);

-лба/-лбэ form verbs with the meaning of acquiring a specifc object or its characteristic from nouns and adjectives, for example: кутл'элбукэндэй (to make smaller) from кутл'эн (small), улбэдэй (to grow old) from утэрэп (ancient, age-old);

-г/-ги form verbs with the meaning of production or the use of objects from nouns, for example: һарандай (to arrange a place for the bed curtain in a teepee) from the hаран (a place for 
the bed curtain in a teepee), алтадай (to remove flesh from skin) from алтӑ (flesh, membrane), ивэдэй (to chop kindling) from ивэллэ (kindling);

-T/-Ta form verbs with the meaning of possession from noun stems: тэтуттэй (to have or to wear clothes) from тэти (clothes);

-ти forms verbs with the meaning of the use of a specific object from nouns, for example:

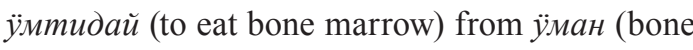
marrow), һактидай (to eat the liver of an animal) from hакӑн (liver);

-ла/-лэ form verbs with the meaning of fetching an object from some inanimate nouns: ондӥладай (to go to bring water) from ондй (water), голладай (to go to bring firewood) from гол (firewood);

-ли forms verbs with the meaning of collecting objects indicated by the stem from some nouns: ондӥлидай (to carry water) from ондӥ (water), голлидай (to prepare firewood) from гол (firewood);

-Л forms verbs with the meaning of condition from the stems of nouns and adjectives, for example: уэрилдэй (to get lighter) from уэрин (light), hатаирӑлдай (to get darker, to darken) from hamăp (darkness, dark);

-y forms verbs with different meanings from nouns, for example: алудай (to put the harness on) from ал (a harness, a strap), инудэй (to load

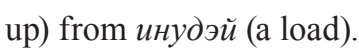

Deverbative suffixal stems are formed with the help of special suffixes of various categorical forms of verb. New verb stem from verbs secondary verb stems - form the suffixes of voice and aspect.

In the descriptions of the Even and the other Manchu-Tungus languages it is customary to use voice forms for several categories capable of changing the actant structure of the verb word form. As a rule, the forms of the active, passive, reflexive middle, causative, reciprocal and cooperative voices are singled out on the basis of morphological criteria in the Even language. With a different approach to the description of the Even language grammar, the same forms are considered as special categories of verbal forms formation within the functional semantic category of voice (Robbek, 2007).

In the Lower Kolyma subdialect, as well as in other subdialects and dialects of the Even language, the most common form of the use of verb in speech is the active voice, which covers almost the entire verbal lexicon and is the starting point for the formation of other voice forms. It does not have a specific morphological indicator. Examples: Д’албу ӭрӭгӭр орӑндула һовнодиттан. (My parents have always worked in reindeer husbandry.) Гуд`эйэ-ке, ноңӑртан ӱнтот тонэчин манӱд'ин гумми сентябрла иһтала тачӥн бивэткэрэчэл ач ӱнтолач. (Poor guys, in order to save their mukluks, they were going barefoot till September). Тадук би тӱнуан һутӭлкэн биһэм, кутл'эн нарикакаму тӱнуан классла таттӑн. (So I have five children, the youngest son studies in the fifth grade).

The form of the passive voice (passive) in the Even language is formed from the transitive and intransitive verbs, the only condition for transforming the active structure into the passive one is the presence of a subject and an object expressed by nouns or pronouns belonging to the class of active names (most often these are the notions of people, sometimes animals). The passive voice forms in the Lower Kolyma subdialect are formed by the suffixes -в-/-ав-/-эв/-ив-/-м-: маввдай (to be killed), бакавдай (to be found), дебэвдэй (to be eaten), дайивдай (to be hidden), һэпкэмдэй (to be caught).

Constructions with transitive verbs that have inactive object are not transformed into passive. For intransitive verbs, the condition for the transition of the original active structure into the passive one is the presence of possessive word combinations in the subject group. In the Even 
language, one of the peculiarities of the active structures transformation into the passive ones is the possibility of displacements of any member of the possessive word combination into the subject position of the passive construction in the subject and object groups.

Differences concerning the formation of the passive forms of verb and the rules for transforming active structures into the passive ones in the Lower Kolyma subdialect are not observed. In the speech of informants, passive phrases are used rarely, for example: льсс бадич ичулчэ биһим, ол иһин мину гэрбуврэтэн илкэдит "Бад'и". (I was born early in the morning, that is why in the Even language I was called Bad'i.)

гэрбу-в-рэ-тэн

name-PASS-PRS-3P1

Тур ӥмандат даһавран. (The earth is covered with snow.)

даh- $a$ - $-p a-\mu$

to cover-PASS-PRS-3Sg

The reflexive middle voice (reflexive) denotes an action that comes from an object and is directed at it, or as if happens by itself. The form of the reflexive middle voice in the Even language is formed from a relatively limited number of verbs, mostly causative ones in their semantics: the basic meaning of this form is uncausative. The forms of the reflexive middle voice are formed from the verb stems by adding suffix -б-//-п, for example: бактай (to find) бакаптай (to be found), эмэндэй (to leave) эмэптэй (to stay).

As far as can be judged from the materials, the forms of the reflexive middle voice in the Lower Kolyma subdialect are used very actively, in contrast to the similar forms in the eastern dialects, while the forms of the reflexive middle voice are represented not only in the personal forms of verbs, but also in the participial and adverbial participle forms, for example: hауанапча (sewed), бэрипчэ (lost), эмэпникэн (staying). Examples: Мэнкэһэл д’омкачилда, эрдин стада миан умэн стада ойдун тала бӭкӭчӭн илэ-тала нодуракат, йак һулабдин. (Think about it, what will remain if we scatter these eleven herds everywhere.)

Һула-б-ди-н

to remain-RFL-FUT-1Sg

Мут ачча оракат турэнти бэрибд'ин. (When we are gone, (our) language will disappear.)

бэри-б-д'и-н

to be lost-RFL-FUT-1Sg

Чакӑпча абдув туйэлэ нэн. (I have put the collected things into my bag.)

чак-ӑn-чa

to collect -RFL-PART.PRF

The causative voice (causative) refers to a subject that causes or makes another person to perform the action. The causative voice forms in the Even language are formed from the unlimited range of verbs by adding suffixes -вкан-/-вкэн/-укан-/-укэн-/-мкан-/-мкэн- to the stem. In the subdialect differences in the formation of causative voice forms are not observed. In the subdialect the causative voice forms are actively used in the forms of participial and adverbial participle, for example: эрэлукэнчэ (went round), уэлукэтникэн (frightening), д`эбукэниди (having fed).

Examples: Өлөрэ турэн бӭкӭчӭн бӭич биһин, тур һовнаримдас урэчин биһин, илэ уэнд’инди тала бэйил, илэ исчинди, тала бӭкӭчӭн стада илаттан, орандари бэй туһуканд’иддин ичуврэн, "Буранат" кун'авканд'иггарар эргидэлэ, илувэттэ уэнэддэкэһ уин гогӑнни иһэнгэрэн. (There used to be people everywhere in the Olerinsk tundra, as if the earth was moving, wherever you go people were everywhere, wherever you look there was a herd everywhere, you could see people going on deer, here they rush on "Buran", and there you could hear dogs barking). 


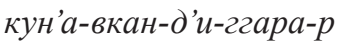

to rush-CAUS-PROC-ITR1-3P1

Д’эбукэнд’ипболлаһурӭлбур. (Feed our children.)

д’эб-укэн-д’и- $n$

to eat-CAUS-PROC-FUT-1Pl

The reciprocal voice form (reciprocal) shows the interaction of two or more subjects with each other simultaneously. The reciprocal voice forms are usually formed from the transitive verbs (from the intransitive verbs they have the meaning of compatibility) by adding suffixes -мат/-мэт, -мач/-мэч: тидэй (taken away) - тисчимэттэй (to take away from each other), укчэндэй (to talk) - укчэнмэттээй (to chat with each other (to know any language). In the subdialect the reciprocal is represented not only in the personal forms of verbs, but also in the forms of participle and adverbial participle, for example: иһчимэчэддил (competing), куниматникан (calling to each other, crying "hallo").

Examples of the reciprocal voice forms use: Ичэһмэткӭрӭрӭn, муһһэмгӭрӭрӭп мээнкэһэл букатын ат турэнӟ. (We are looking at each other and smiling to each other without words.)

ичэ- $h$-мэт-кӭрӛ-рӭ- $n$

to look-HAB2-REC-ITR1-PRS-1P1

Би н'ан ноуӑртун'ун умэтту укчэнмэткӭрӭрӭм. (I am also talking together with them.)

укчэн-мэт-кӭрӭ-рӭ-м

to talk-REC-ITR1-PRS-1Pl

The cooperative voice form (cooperative) refers to an action of two or more actors performing this action together. The cooperative voice form in the Even language is formed by adding suffixes лда-/-лдэ-: оукалдадай (to graze together in one place (about animals), гөлдэдэй (to agree, to come to an agreement). In the materials of the Lower Kolyma subdialect this voice form has not been found. The meaning of consistency is transmitted using nouns and pronouns in the common case.

Thus, it is possible to distinguish the following features in the formation and use of the forms of voice in the described subdialect: the active, passive, reflexive middle, causative, reciprocal and cooperative voices are used in the subdialect. There is no cooperative voice form (cooperative). In the colloquial speech of the Lower Kolyma Evens, passive constructions and passive phrases are rarely used. The forms of the reflexive middle voice are very actively used in the subdialect, while these forms are represented not only in the personal forms of verbs, but also in the forms of participle and adverbial participle.

In the scientific literature on the Even language the forms of verb expressing various aspects of the course of action have been called the aspect forms of the verb. They are featured in all grammatical essays and dialectological works; specific monographic studies are devoted to them. However, despite this, in some dialects, as well as in the Lower Kolyma subdialect, it is possible to find some indicators of the nature of the course of the action, that were not featured in the well-known studies.

According to the semantic and grammatical characteristics, the aspects of the Even verb expressing the nature of the course of action are differentiated into six aspect groups (Robbek, 2007: 359). In accordance with these aspect groups, the arsenal of the aspect forms in the Lower Kolyma subdialect is represented quite widely.

The aspect group of the phase of action includes aspect forms expressing various stages of the course of action.

The inceptive aspect form has the meaning of the beginning of an action, it is formed by adding the suffix -л, for example: ауадай (to open) - ауалдай (start opening), дуктай (to write) - дукалдай (start writing). Examples of 
the inceptive aspect form use in the subdialect: Эн'му альс гор икэрикэн би икэдникэн һоуод'алгарарам. (When my mother sang for a long time, I started crying.)

Һоң-од'-ал-гара-ра-м

to cry-PROC-INCH-ITR1-PRS-1Sg

Ноуан нан һадун укчэнэлгэрэн. (She also starts talking differently sometimes.)

укчэнэ-л-гэрэ-н

to talk-INCH-ITR1-3Sg

The imperfective aspect form (imperfective), expressing the incompleteness of an action at the time of speaking or the duration of an action, is formed by the suffix -д/-д'-: тиктэй (to fall) - тикэддэй (to be falling), илдай (to stand up) - иладдай (to be standing), гөндэй (to say) - гөндиддэй (to be saying).

Examples of the imperfective aspect forms use in the subdialect: Д'албу эрэгэл орандула һовноддитан. (My parents have always worked in reindeer herding.)

Һовно-д-ди-тан

to work-PROC-PST-3P1

Тар курин' н’экэддэм, альс наһа эдэн һоуда, ноуантикин би кэн'элив эчин бидэн һурдэку. (I do it on purpose so that he won't not cry a lot, let me be bad for him when I leave.)

$\mu^{\prime} э к-\ni \partial-\partial э-м$

to do-PROC-PRS-1Sg

The continuous aspect form (durative) that expresses the progressive state which is preserved at the moment of speech or the moment of time reference in relation to another action, is formed by suffixes $-\mathrm{T} /$ ч-: тэгдэй (to sit) - тэгэттэй (to be sitting), илдай (to stand up) - илатmай (to be standing).

Examples: Амму д’апканмиар надан ануаниунай иһтала тэгэттин. (My father lived up to eighty-seven years.)

мэг-эm- $m u-н$

to sit-DUR-PST-3Sg

Тар мину боллар амму экэнни иргэттин. (And my sister brought me up). иргэ- $-m-m u-н$

to bring up- DUR-PST-3Sg

Aspect group of the frequency of action (iterative aspect) includes specific indicators of various types of frequency and multi-objective nature of actions.

The frequently performed action aspect form (iterative 1) that denotes a repeatedly performed action, is formed by suffixes -гра-/грэ-//-гара-/-гэрэ-//-нра-/нрэ-: маградай (to kill, to get) - маградай (to kill, to get), гөндэй (to say) - гөугрэдэй (to say (repeatedly). In the lower Kolyma subdialect, the suffix can have the form вра. Examples of its use in the subdialect: Ирили одакан тала уэнгэрэп, һайтав чикинаврарап. (When summer comes we go there to cut hay.)

$$
\begin{aligned}
& \text { уэн-гэрэ- } n \\
& \text { to go-ITR1-1P1 } \\
& \text { чикина-вра-ра- } n \\
& \text { to cut-ITR1-PRS-1P1 }
\end{aligned}
$$

The frequent action aspect form (iterative 2) denotes a multiple, frequently observed action, it is formed by suffixes -кат/ч-//-кэт/ч-, for example: нулгэдэй (to nomadise) - нулгэкэттэй (to nomadise (to nomadise for short period, often or in many places), $и д э \check{и ~(t o ~ c o m e ~ i n) ~-~} и к э т т э \check{и ~}$ (to come in often (to many houses).

Examples: Тадук эчин эрэликки унэм одид’ур тадук эн'эн'ун оралбу мултукатча, йав ок итчир кууа эрэ, йак эрэ. (Having constructed a tepee, they untied the deer with their mother, when they could notice if there were children or somebody else.)

мулту-кат-ча

to set free-ITR2-PART.PRF

Тиниптук һимнэкэттэм, тигэми билгову йaн. (I have been coughing from yesterday, that is why my throat hurts.)

Һимнэ-кэт-тэ-м
to cough-ITR2-PRS-1Sg

The multi-objective action aspect form (iterative 3 ) denotes an action directed at a lot of 
objects, or an action that is divided into different spatial spheres. It is formed by the suffix $-\mathrm{H}-/ \mathrm{H}$ : мадай (to kill) - мандай (to kill, to get several animals), нулгэдэй (to nomadise) - нулгэндэй (to nomadise and nomadise (repeatedly, in different places). For example: Кутл’эн куна эрэк уркэлэ нандан. (The little child constantly stumbles upon this door.)

$\mu a-\mu-\partial a-\mu$

to stumble-ITR3-PRS-3Sg

The usually performed action aspect form (habitual 1) that expresses relative regularity of an action performed irrespective of the moment of speech, is formed by suffixes -ват/ч-//-вэт/ч-: гадай (to take), гаваттай (take usually), гөндэй (to say) гөвэттэй (say usually.)

Examples: $\quad$ Тала учуталауат гиркавачатгаран. (Our teacher usually walks around there.)

гирка-вач-ат-гара-н

to walk-HAB1-DUR-ITR1-3Sg

Һан няри һутэлбу бэкэчэн тик пастуктар, стадала һовнадда, нулгэвэчиддэ. (Other sons are all shepherds, they work in the herd, they always nomadise.)

нулгэ-вэч-ид-дэ

to nomadise-HAB1-PROC-3P1

The continuously repeated aspect form (habitual 2), which expresses a continuous and repeatedly or constantly performed action, is formed by the suffix -c-, for example: нөдэц̆ (to step out) - нөстэй (step out), эмдэй (to come) эмэстэй (come (repeatedly). In the Lower Kolyma subdialect the suffix is pronounced as $-h$.

Examples of its use in the subdialect: H'apu буйуһгэрэн, буйуһниди, һурми бонкан дован умуврэн. (The man hunts, having hunted, he brings the offal of the prey.)

$$
\begin{aligned}
& \text { буйy- } h \text {-гэрэ- } \\
& \text { to hunt-HAB2-ITR1-3Sg }
\end{aligned}
$$

Эчин һунуэ долан эчин имандав эчин чоукоһгарача, эчин көйэткэрэчэ тарак турлэ бичэ биһэп гуннэчэ. (That is how he shoveled snow during the snowstorm, looked intensely and said where we are.)

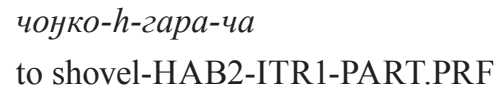

The continuous weakened action aspect form (continuative) denotes a progressive or repeated action, occurring with a low intensity or speed. It is formed by suffixes -дян-/дян'-//-ден/-ден '-: уэндэй (to walk) - уэнэдендэй (to walk (calmly, slowly, leisurely, with difficulties), гөндэй (to say) - гөндидендэй (to speak (slowly, calmly).

Examples of the progressive weakened action aspect forms use in the subdialect: Илэтала тэгэтникэн ирэв-тарав ичукэткэрэн, эрэгэл укчэнэд'эугэрэн. (Sat here and there and showed different things, always told about something.)

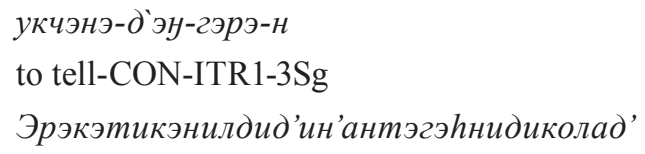
андан. (Having come in, this old man sat down and started smoking slowly.)

кола-д’ан-да-н

to smoke-CON-PRS-3Sg

Aspect group of the direction of action combines the aspects of the verbs denoting action, the fulfillment of which is associated with the spatial relocation or shift in time with respect to other actions.

The departure aspect form (departure 1) indicates an action, accompanied by the actor's movement. It is formed by suffixes -на/-нэ, for example: мадай (to get) - манадай (to go to get), иттээй (to see, to look) - итнэдэй (to go to see).

Examples of its use in the subdialect: Орарбу итнэдэи нэкэддэн. (Going to go to look at the deer.)

ит-нэ-дэи

to look-DEP1-INF

Голу чикинадан. (Is going to cut the firewood (he).) 
чики-на-да-н

to cut-DEP1-PRS-3Sg

The opposite action aspect (appositive 1) denotes an action opposite in its meaning to the action indicated by the initial stem. It is formed by suffixes -лга-/-лгэ-, for example: алудай (to harness deer) - алулгадай (to unharness deer), ильчадай (to braid) - ильчалгадай (to unbraid).

Examples of use in the subdialect: Оралчимуа мавуту учалгаддан. (The reindeer herder unwinds the lasso.)

уча-лга- $-\partial а-н$

to wind up-OPP1-PROC-PRS-3Sg

КиаБа учаки алалган. (Grandfather took off the halter from his reindeer.)

ала-лга-н

to put on. the halter-OPP1-3Sg

Aspect group of the intensity of action includes two aspect forms - the accelerated action aspect and intensive aspect.

The accelerated action aspect form (intensive) denotes an action taking place at a considerable speed and is formed by suffixes -малчи-/-мэлчи-, for example: минэдэй (to cut off) - минэмэлчидэй (to cut off quickly), уэндэй (to walk) - уэнэмэлчидэй (to walk quickly).

Examples: Акму һовнантикии һурэмэлчин. (The older brother is going to work in a hurry.)

Һурэ-мэлчи-н

to go-INT-3Sg

Упэһэгэрникэнондилактукондивһукума лчин. (Grandmother dips the water from the ice hole hastily).

\section{һуку-малчи-н \\ to dip-INT-3Sg}

The single-action aspect form (momentary) expresses the single nature of an action, has the meaning of the increased intensity of action in the emotionally loaded contexts. It is formed by suffixes -сан-/-сэн-/-сн- (-haн/-hэн/-hн variant is typical to the Lower Kolyma subdialect): хондай (to hit) - хонасандай (to hit once, to hit hard), төрэндэй (to speak) - төрэсэндэй (to speak (briefly, sharply, emphatically). Examples: Умнэкэн эһэчэдникэн гиркаддам, арай йаһнирам, һимкэһнэм олукаду. Эргидэтки ичэһнэм иту дэгилдэн, протеhy. (I was going slowly, glanced back, and at this time I coughed. I looked, and saw my tooth, my dental prosthesis going out.)

Һимкэ- һн-эм

to cough-MOM-1Sg

ичэ-

to look-MOM-1Sg

Ниаритуйум һэпкэһэнчэ-дэ һурчэ. (The young men grabbed the staff and went away.)

Һэпкэ-һэн-чэ-дэ

to grab-MOM-PART.PRF-PRTCL

Aspect group of desiderative action includes types of verb that express desire and aspiration to perform an action.

The desire to perform an action aspect form (desiderative) has a meaning of desire, intention, and inclination to accomplish an action. It is formed by the suffix - $\mathrm{M}^{-}$and indicative indicators -ca-/-cэ- for the present tense and -си- for the past tense (in the Lower Kolyma subdialect variants $-h a /-h \ni /-h u$ correspondingly), for example: хуклэдэй (to fall asleep) - хуклэмдэй (to feel sleepy), хуклэмсэм

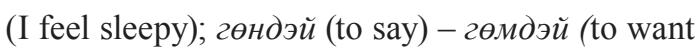
to say), гөмсэн (he wants to say). Examples of the desiderative aspect use in the subdialect: Тачин муту таткаттитан, тигэми боллар би укчэнгэрэрэм таров обычайу, эр куналтики би таров таткачамһам. (This is how we were taught, that is why I tell about this custom and I want to teach this the children.)

таткача-м-ha-м

to teach-DES-PRS-1Sg

һули куна һуклэмиин. (The baby felt sleepy.)

Һуклэ-м- $и$-н

to sleep-DES-PST-3Sg 
The delayed action or the desire to perform an action aspect form (diminutive 1) with the suffix - счи indicates an attempt or an aspiration to perform an action. This form also denotes an action delayed in time, which has a weakened intensity, that does not reach a result or is in the initial stage, for example: хауандай (to sew) хауанасчидай (to try to sew, to sew (slowly, not hastily), удандай (to rain) - удасчидай (to rain, to drizzle).

Examples: Д’э, татасчидам һауандай гуми. Д’э, элэкэһ йалдивун бу оһолалбу кочайасчилдам, нандалбу исчилдам. (So, I started trying to learn sewing. I started trying to prepare climbing skins, trying to prepare skins.)

тат- $а с ч и-д а-м$

to learn-DIM1- PRS-1Sg

кочай-асчи-л-да-м

prepare. climbing skins-DIM1-INCH-PRS$1 \mathrm{Sg}$

$u-c ч u-л-\partial a-\mu$

prepare.skin-DIM1-INCH-PRS-1Sg

Тарак һагдилти гусчиритэн: «ЭӘ'иһил ноңарбутан һундикир. Матми бими букатын мадина». (Then our old people tried to warn: "Do not touch them (the wolves). If you kill, you have to finish off").

гу-счи-ри-тэн

to say-DIM1-PST-3P1

The aspect class of an action imitation is represented by a single aspect form, indicating imitation of an action, expressed by the notional verb stem. In the literary Even language and the subdialects of the Eastern dialect, the action imitation aspect is formed by the analytical construction: suffixes caH/-сон/-сэн + verb бидэй (to be), for example: долчисан бидэй (to pretend to listen), колсон бидэй (to pretend to drink).

In the Lower Kolyma subdialect, the action imitation aspect is formed according to the following scheme: participial stem + comparative form (comparative) -гчин/-вчин + auxiliary verb бидэй (to be). The basic meaning of an action repetition or imitation is in the participial stem, formed by the comparative -гчин/-вчин, which expresses neither a person nor a number. The auxiliary verb бидэй (to be) is supplemented by the morphological indicators of aspect, tense, person and number.

Examples: Таткачимуа ирэкэн, мут тауадивчин биврэрэп. (When the teacher comes in, we pretend to read).

тау-ади-вчин би-врэ-рэ- $n$

to read-PART.PRS-CMPR to be-ITR1PRS-1Pl

Этикэн иһчалан, һуличан көкэчэвчин биһин. (When the old man approached, the fox pretended to be dead.)

көкЭ-чЭ-вчин

бu- $h u-\mu$

to die-PART.PRF-CMPR

to bePST-3Sg

The available materials on the Lower Kolyma subdialect suggest that, in addition to the above aspect forms, certain forms of the verb aspect that were not previously recorded in the existing grammatical descriptions of the Even language and other dialects and subdialects are also found.

The single intense action form (ultramomentary aspect) is formed by the suffix -нукан/-нукэн and gives the meaning of an action momentariness and intensity. In contrast to the single action aspect (momentary aspect), it expresses even more extreme shortness of an action, its higher intensity. According to our data, the single intense action form is used both in the eastern and western dialects of the Even language. This form can be attributed to the aspect group of the intensity of action.

Examples of its use in the Lower Kolyma subdialect: Олукаду нуңа паһануканни. (Suddenly the shot banged.)

паһа-нукан-ни

to bang- UMO-3Sg 
Ниарикан эмкэрдук һурунукэнни. (Тhe young man came down from the mountain very quickly.)

\section{һуру-нукэн-ни \\ to leave-UMO-3Sg}

The constantly performed action form (habitual 3) in the Lower Kolyma subdialect denotes a habitually performed action and is formed by the suffix -уна/-унэ. In its meaning, this form is correlated with the usually performed action aspect formed by -ват/ч-//-вэт/ч-, expressing the relative regularity of an action performed irrespective of the moment of speech. According to our data, this form is also used in other subdialects of the Western dialect. The form can be attributed to the aspect group of the frequency of action.

Examples of the constantly performed action form use in the Lower Kolyma subdialect: Адалy тунэррэ илукаунар. (The fishing net is set on the lake.)

ил-ука-уна- $p$

to set-CAUS-HAB3-3PI

Тадук эмдэкэттэн болла, hиату эчин эрэ калталдид'ур, эчин эрэ тарак тар долин бэйил могиладук эмдид’ур иэлтэннэр. (When they come from there, they splinter willow twigs and people who come from the cemetery pass through it.)

иэлтэ-ннэ- $p$

to pass-HAB3-3P1

Һадун долбини дулокандун өриннэрэп первэй час деки-да. (Sometimes in the middle of the night, after midnight, we make a camping ground.)

өри-унэ-рэ- $n$

make.camping ground-HAB3-PRS-1Pl

The repeated weakened action form (iterative 4), the meaning of which is to be clarified, is formed by the suffix -тна/-тнэ. In the Lower Kolyma subdialect, the author of this article preliminary defines this form as indicating a repeated weakened action with an additional connotation of spontaneous performance. This form can be attributed to the aspect group of the frequency of action.

Examples of its use in the Lower Kolyma subdialect: Бакарһи буһкэли тикэтнэрит. (We fell and fell on slippery ice.)

тик-этнэ-ри-т

to fall-ITR4-PST-1P1

Тиниптук һемкэллиди, нипкутнэрив. (Since yesterday I chink and chink because of cough.)

\section{нипку-тнэ-ри-в}

to chink-ITR4-PST-1Sg

The form of differed action with a modal connotation of pity (diminutive 2), characterized by suffixes -йат/-йэт/-йач/-йэч, means that an action or a dynamic image manifests itself in a slowed rate and is characterized by a modal connotation of certain sympathy, affection, pity or regret in relation to the subject of action from the speaker's part. This form can be preliminary attributed to an aspect group of the intensity of action.

Examples of -йат/-йэт/-йач/-йэч form use in the Lower Kolyma subdialect: Эн'му адукутта абдучалби гача, нолимала тэгэйэччэ. (Mom took a few things and sat on the sledge, poor thing.)

тэг-эйэч-чэ

to sit-DIM2-PART.PRF

Амму гуд’эике мунуавриди тар пэктурэми һэпкэниди, куратлии нукриди, д’э улкуйаттан. (Poor father grabbed his rifle with annoyance and having taken off his hat, started swinging it.)

улку-йат-та-н

to swing-DIM2-PRS-3Sg

The above gives grounds for identifying the following peculiarities in the formation and use of the aspect category types and verbal action methods in the Lower Kolyma 
subdialect. The action imitation aspect in the Lower Kolyma subdialect is formed by the analytic construction: a participial stem with the comparative form -гчин/-вчин + auxiliary verb бидэй (to be). Four forms of the verb aspect that has not been mentioned in grammatical descriptions are used in the subdialect: the intense single action form (suffixes -нукан-/нукэн); the permanent action form (-нна/-ннэ); the repeated weakened action form (-тна-/тнэ-); the deferred action form with a modal connotation of pity (-йат//ч-/-йэт//ч-).

There is absence of the following aspect forms typical to other dialects and subdialects: the rarely performed action form (-ван/-вэн//ин); the weakened action form (-co); the form of repeated departure for an action performance (-ни); the opposite action form (-рга/-ргэ).

The speech of the Lower Kolyma Evens is characterized by the highest frequency of use of the usually performed action aspect forms (-ват/ ч-//-вэт/ч-), the repeatedly performed action forms (suffixes -гра-//-грэ-//-гара-//-гэрэ) and the constantly performed action forms (suffix -нна/ннэ).

\section{Signs and Symbols}

1 - first person; 2 - second person; 3 - third person; CAUS -causative; CMPR -comparative; CON - continuative; DEP1 - departure 1; DEP2 - departure 2; DES - desiderative; DIM1 diminutive 1; DIM2 - diminutive 2; DUR durative; FUT - future tense; HAB1 - habitual 1; HAB2 - habitual 2; HAB3 - habitual 3; INCH inchoative; INT - intensive; ITR1 - iterative 1; ITR2 - iterative 2; ITR3 - iterative 3; ITR4 iterative 4; INF - infinitive; MOM - momentary; OPP1 - appositive 1; OPP2 - appositive 2; PASS - passive; PART.PRS - present participle; PART.PRF - perfect particle; Pl - plural; PROC processivity; PRS - present tense; PST - past tense; PRTCL - particle; REC - reciprocal; RFL - reflective; Sg - singular; UMO - ultramomentary aspect.

\section{References}

Burykin, A.A. (2004). Iazyk malochislennogo naroda $v$ ego pis'mennoi forme [SmallNumbered People Language in Its Written Form]. Saint Petersburg, Peterburgskoe Vostokovedenie, $373 \mathrm{p}$.

Charekov, S.L. (2004). Semanticheskaia struktura slovoobrazovaniia v russkom i altaiskikh iazykakh [Semantic Structure of Word Formation in the Russian and Altai Languages]. Saint Petersburg, Nauka, 104 p.

Robbek, V.A. (1982). Vidy glagola v evenskom iazyke [Types of Verbs in the Even Language]. L., $112 \mathrm{p}$.

Robbek, V.A. (1984). Kategoria zaloga v evenskom iazyke [Category of Voice in the Even Language]. L., 188 p.

Robbek, V.A. (2007). Grammaticheskie kategorii evenskogo glagola v funktsional'nosemanticheskom aspekte [Grammatical Categories of the Even Verb in Functional and Semantic Aspects]. Novosibirsk, Nauka, 726 p.

Sharina, S.I. (2014). Nekotorye osobennosti iazyka nizhnekilymskikh evenov [Some Peculiarities of the Lover Kolyma Evens' Language], In Filologicheskie nauki. Voprosy teorii i praktiki [Philological Sciences. Issues of Theory and Practice], Tambov, Gramota, 8, (II), 191-193.

Sharina, S.I. (2017). The Denominative Verbal Word-Formation in Nizhnekolymsky Dialect of the Even Language, In The Scientific Heritage, Vol. 2. 9(9), 123-125. 


\section{Глагольное словообразование в нижнеколымском говоре эвенского языка}

\section{С.И. Шарина}

Северо-Восточный федеральный университет

им. М.К. Аммосова

Россия, 677000, Якутск, ул. Белинского, 58

В статье рассматривается система глагольного словообразования в не имеющем системного описания нижнекольмском говоре эвенского языка. Нижнекольмский говор, относящийся $\kappa$ западному наречию, обладает рядом отличительных черт на всех уровнях языка. В сфере глагольного словообразования эти различия проявляются в фонетических и лексических особенностях говора, в составе суффиксов определенных морфологических категорий глагола и их структуре, а также в частотности употребления показателей.

Материалом для написания статьи послужили данные автора, собранные во время полевых экспедищий в Нижнекольлском районе Республики Саха (Якутия) в 2013-2015 г2.

Ключевые слова: эвенский язык, нижнекольмский говор, словообразование глаголов, отыменное словообразование, отглагольное словообразование.

Научная специильность: 10.00.00 - филологические науки. 